\title{
Water Resources of Beauregard Parish
}

\section{Introduction}

In 2005, about 30.6 million gallons per day (Mgal/d) of water was withdrawn in Beauregard Parish, Louisiana (fig. 1), including about $30.4 \mathrm{Mgal} / \mathrm{d}$ from groundwater sources and $0.1 \mathrm{Mgal} / \mathrm{d}$ from surface water sources ${ }^{1}$ (table 1). Industrial use, primarily for wood products, accounted for about 72 percent $(22.0 \mathrm{Mgal} / \mathrm{d})$ of the total water withdrawn. Other categories of use included public supply, rural domestic, livestock, rice

${ }^{1}$ Tabulation of numbers across text and tables may result in different totals because of rounding; nonrounded numbers are used for calculation of totals. irrigation, general irrigation, and aquaculture (table 2). Wateruse data collected at 5-year intervals from 1960 to 2005 (fig.

2) indicate water withdrawals in the parish peaked at about 43.5 Mgal/d in 1985. The large increase in groundwater usage from 1970 to 1975 was primarily due to industrial withdrawals, which increased from $3.64 \mathrm{Mgl} / \mathrm{d}$ in 1970 to $29.0 \mathrm{Mgal} / \mathrm{d}$ in 1975.

This fact sheet summarizes information on the water resources of Beauregard Parish, La. Information on groundwater and surface-water availability, quality, development, use, and trends is based on previously published reports listed in the Selected References section.
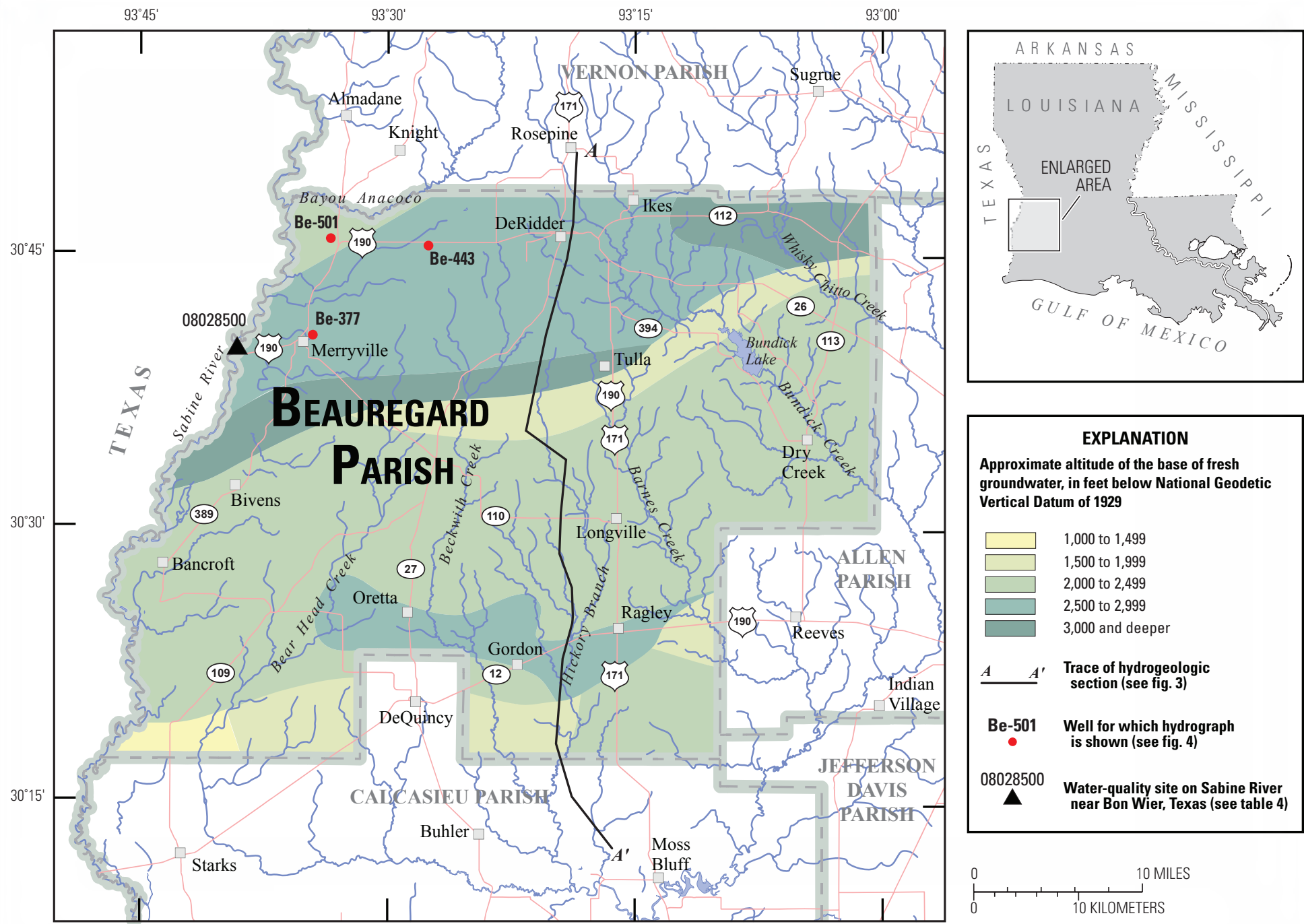

Base map modified from Louisiana Department of Transportation and Development (1986)

Figure 1. Location of study area, Beauregard Parish, Louisiana. 
Table 1. Water withdrawals, in million gallons per day, by source in Beauregard Parish, Louisiana, 2005 (modified from Sargent, 2007).

\begin{tabular}{lcc}
\hline $\begin{array}{c}\text { Aquifer, aquifer system, } \\
\text { or surface-water body }\end{array}$ & Groundwater & Surface water \\
\hline Chicot aquifer system & 12.35 & \\
Evangeline aquifer & 3.19 & \\
Jasper aquifer system & 14.92 & \\
Miscellaneous streams & & 0.10 \\
\cline { 2 - 3 } Total & 30.45 & 0.10 \\
\hline
\end{tabular}

Table 2. Water withdrawals, in million gallons per day, by category in Beauregard Parish, Louisiana, 2005 (modified from Sargent, 2007).

\begin{tabular}{lccr}
\hline \multicolumn{1}{c}{ Category } & Groundwater & $\begin{array}{c}\text { Surface } \\
\text { water }\end{array}$ & Total \\
\hline Public supply & 3.73 & 0.00 & 3.73 \\
Industrial & 22.01 & .00 & 22.01 \\
Rural domestic & .77 & .00 & .77 \\
Livestock & .08 & .06 & .14 \\
Rice irrigation & 3.23 & .00 & 3.23 \\
General irrigation & .40 & .04 & .45 \\
Aquaculture & .23 & .00 & .23 \\
Total & 30.45 & .10 & 30.55 \\
\hline
\end{tabular}

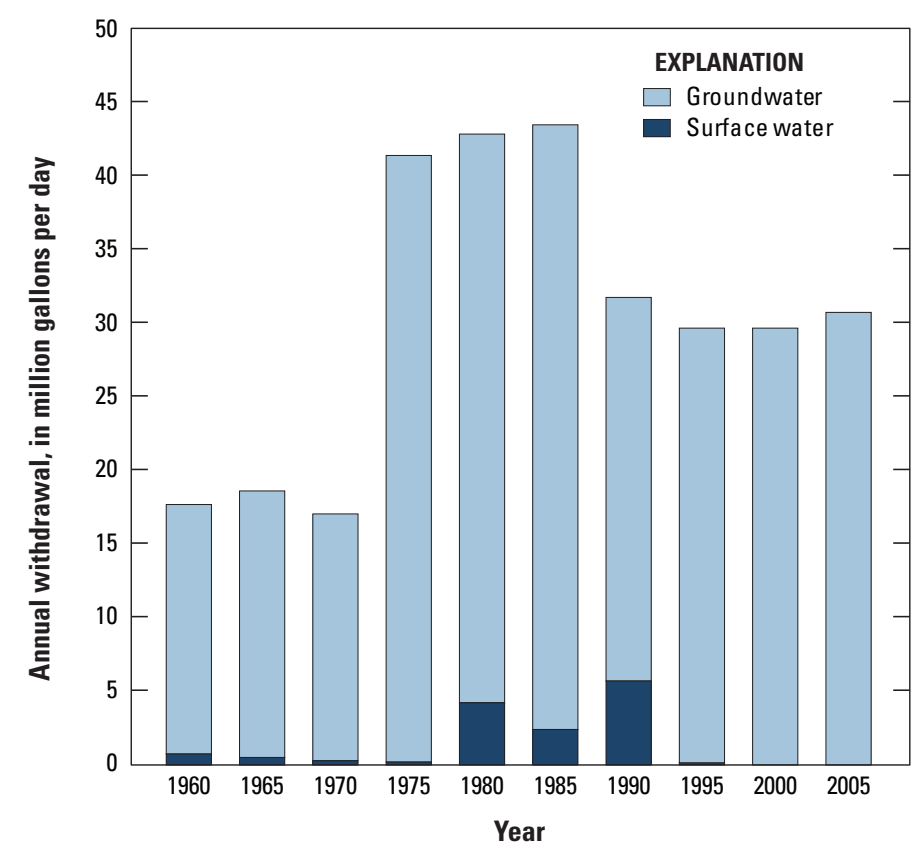

Figure 2. Water withdrawals in Beauregard Parish, Louisiana, 1960-2005.

\section{Groundwater Resources}

The groundwater resources of Beauregard Parish, from near surface to deepest, include the Chicot aquifer system, Evangeline aquifer, and Jasper aquifer system (fig. 3). Deeper aquifers in Beauregard Parish contain only saltwater (water with chloride concentrations greater than 250 milligrams per liter $[\mathrm{mg} / \mathrm{L}])$. The base of fresh groundwater generally ranges about 2,500 to 3,000 feet (ft) below the National Geodetic Vertical Datum of 1929 (NGVD 29) (sea level) in the northern part of the parish, about 2,000 to 2,500 ft below NGVD 29 in the central part, and about 1,000 to 2,000 ft below NGVD 29 in the southern part (fig. 1). Recharge to aquifers in Beauregard Parish is from precipitation, leakage from overlying aquifers, and seasonal input from rivers. Discharge from aquifers is by natural flow into rivers, leakage into underlying aquifers, and withdrawals from wells.

State well-registration records listed 901 active water wells in Beauregard Parish in 2009, including 753 domestic, 78 irrigation, 44 public-supply, and 26 industrial wells. In 2005 , categories of use for groundwater withdrawals in Beauregard Parish included public supply, industrial, rural domestic, livestock, rice irrigation, general irrigation, and aquaculture (table 2).

\section{The Chicot Aquifer System}

In most of Beauregard Parish, the Chicot aquifer system is composed of two sand units (aquifers) - the shallow sand and the deeper undifferentiated sand - and contains freshwater throughout the parish. The shallow sand is present within a clayey surficial confining unit, which generally ranges in thickness from less than $40 \mathrm{ft}$ in northern areas of the parish to $120-160 \mathrm{ft}$ in southwestern areas of the parish. The shallow sand is composed of scattered sand streaks, lenses, and layers that can provide water for domestic purposes.

State well-registration records listed 102 active wells screened in the shallow sand in Beauregard Parish in 2009, including 99 domestic and 3 irrigation wells. All but four of these wells are located in northern and northeastern areas of the parish. Depths of these wells ranged from 11 to $88 \mathrm{ft}$ below land surface, with a median depth of $26 \mathrm{ft}$. In 2005, withdrawals from these wells were about $0.17 \mathrm{Mgal} / \mathrm{d}$ and included about $0.14 \mathrm{Mgal} / \mathrm{d}$ for rural domestic use and about $0.03 \mathrm{Mgal} / \mathrm{d}$ for livestock. No water-quality data were available for these wells.

The undifferentiated sand unit is present throughout Beauregard Parish and is the primary component of the Chicot aquifer system within the parish. It is composed of beds of clay, silt, sand, and gravel. Single beds of sand are usually massive and can attain thicknesses of several hundred feet. Individual sand beds usually grade from fine sand at the top to coarse sand and gravel at the base. The altitude of the base of the undifferentiated sand unit ranges from about $0 \mathrm{ft}$ NGVD 29 near the town of DeRidder to about 400-500 ft below NGVD 29 along the southern parish line (fig. 3). Close to the southeastern parish line, the undifferentiated sand unit is subdivided by clays into two or more sand subunits as it enters into Calcasieu Parish. In 2005, about $0.16 \mathrm{Mgal} / \mathrm{d}$ of groundwater was withdrawn from these subunits in Beauregard Parish.

Infiltration of precipitation in southern Vernon Parish and the northern half of Beauregard Parish is the primary source of recharge to the undifferentiated sand unit in Beauregard Parish. Vertical leakage of water through clays is a secondary source. Water movement in the undifferentiated sand unit in Beauregard Parish is generally southward from the recharge area or westward towards the Sabine River.

In 2003, water levels in the undifferentiated sand unit in Beauregard Parish ranged from about $160 \mathrm{ft}$ above NGVD 29 


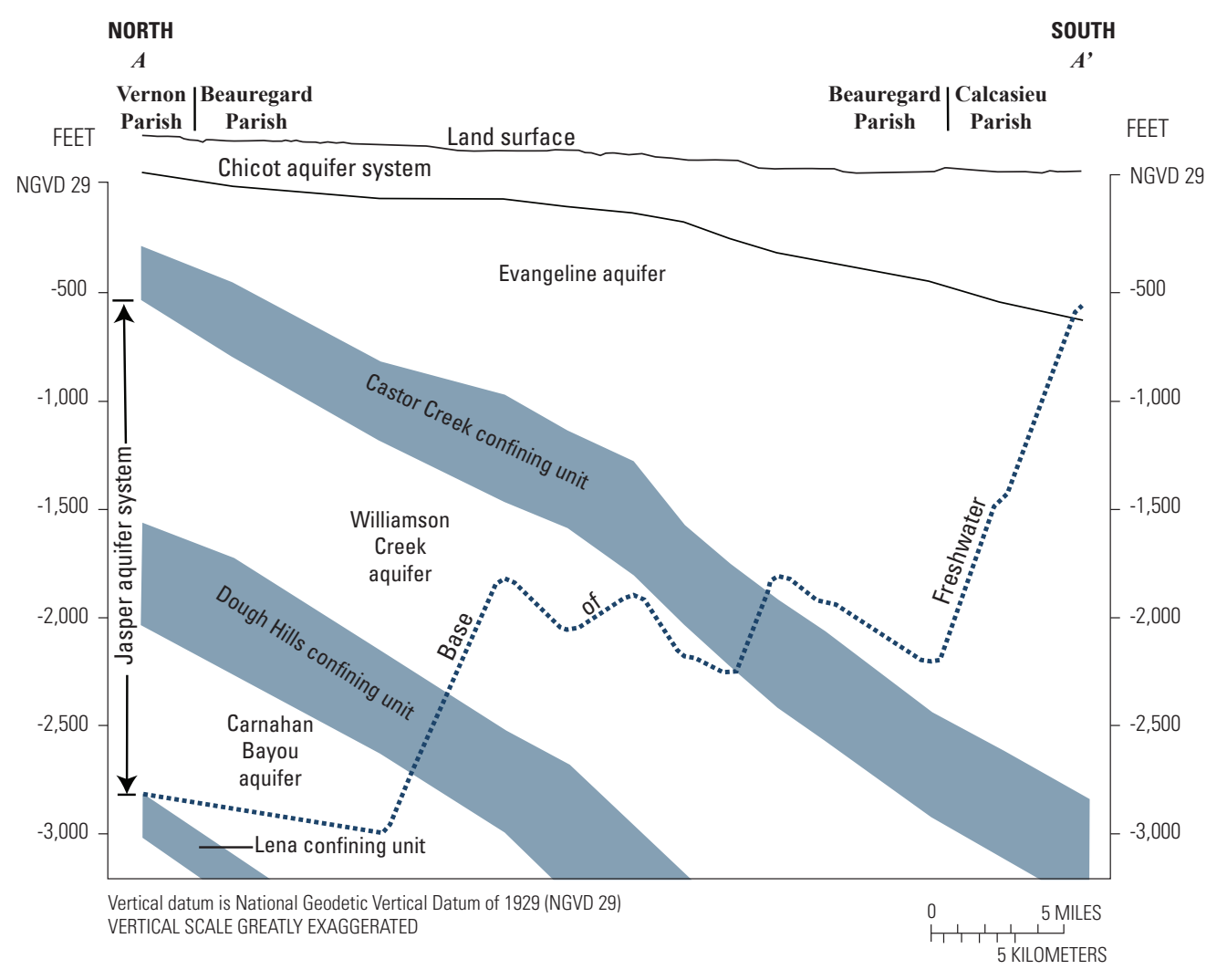

Figure 3. Generalized north-to-south hydrogeologic section showing aquifer and confining unit intervals (individual sand and clay layers not shown) from Vernon Parish to Calcasieu Parish, Louisiana (modified from Whitfield, 1975, plate 3). Trace of section shown on figure 1. near the town of DeRidder to $20 \mathrm{ft}$ below NGVD 29 near the southeastern parish line. Water levels in the undifferentiated sand unit generally fluctuate 1 to $2 \mathrm{ft}$ annually, as shown in the hydrograph of well Be-443 (fig. 4), which is located west of DeRidder in northern Beauregard Parish (fig. 1). The hydrograph shows a slight decline in water level during 1999-2000, a period of reduced precipitation.

State well-registration records listed 619 active water wells screened in the undifferentiated sand unit in Beauregard Parish in 2009, including 523 domestic, 60 irrigation, 23 public supply, and 13 industrial wells. Depths of these wells ranged from 16 to $461 \mathrm{ft}$ below land surface and had a median depth of $125 \mathrm{ft}$. Reported yields from wells screened in the undifferentiated sand unit in Beauregard Parish range from about 10 to 3,500 gallons per minute (gal/min). In 2005, withdrawals from the undifferentiated sand unit in Beauregard Parish were about $12.0 \mathrm{Mgal} / \mathrm{d}$ and included about $2.44 \mathrm{Mgal} / \mathrm{d}$ for public supply, $5.53 \mathrm{Mgal} / \mathrm{d}$ for industrial use, $0.60 \mathrm{Mgal} / \mathrm{d}$ for domestic use, $0.05 \mathrm{Mgal} / \mathrm{d}$ for livestock, $2.83 \mathrm{Mgal} / \mathrm{d}$ for rice irrigation, $0.34 \mathrm{Mgal} / \mathrm{d}$ for general irrigation, and $0.23 \mathrm{Mgal} / \mathrm{d}$ for aquaculture.

A statistical summary of selected water-quality characteristics for 62 wells screened in the undifferentiated sand unit in Beauregard Parish is listed in table 3. Generally, water from the undifferentiated sand unit is soft $(60 \mathrm{mg} / \mathrm{L}$ or less as calcium carbonate) and does not exceed the U.S. Environmental Protection Agency's (EPA) Secondary Maximum Contaminant Levels (SMCLs) ${ }^{2}$ for drinking water for color and chloride, iron,

${ }^{2}$ The SMCLs are nonenforceable Federal guidelines regarding cosmetic effects (such as tooth or skin discoloration) or aesthetic effects (such as taste, odor, or color) of drinking water. At high concentrations or values, health implications as well aesthetic degradation might exist. SMCLs were established as guidelines for the states by the U.S. Environmental Protection Agency (1992). manganese, and dissolved solids concentrations. Locally, iron and manganese concentrations can greatly exceed the SMCLs of 300 and 50 micrograms per liter $(\mu \mathrm{g} / \mathrm{L})$, respectively. The median $\mathrm{pH}$ value of 6.3 (listed in table 3 ) is below the SMCL range of $6.5-8.5$.

\section{The Evangeline Aquifer}

The Evangeline aquifer underlies the Chicot aquifer system and overlies the Castor Creek confining unit in Beauregard Parish (fig. 3). The aquifer is continuous throughout the parish and generally dips to the south. Freshwater is present throughout the aquifer except near the southern parish line where the lower part of the aquifer contains saltwater (fig. 3). The Evangeline aquifer primarily consists of fine to medium sand that is interbedded with silt, soft to moderately hard greengray laminated clay, and local beds of coarse sand. Locally, sands within the aquifer are separated and confined by clays. Thickness of the Evangeline aquifer in Beauregard Parish generally ranges from about $500 \mathrm{ft}$ near the town of DeRidder to about 2,000 ft near the southeastern corner of the parish. The altitude of the top of the aquifer is about $0 \mathrm{ft}$ NGVD 29 near DeRidder and about 400-500 ft below NGVD 29 near the southern parish line.

Water movement in the Evangeline aquifer in Beauregard Parish is generally to the south or southwest. In 2004, water levels in the Evangeline aquifer in Beauregard Parish ranged from about $140 \mathrm{ft}$ above NGVD 29 near the northeastern corner of the parish to about $20 \mathrm{ft}$ below NGVD 29 near the southwestern corner of the parish. Water levels generally fluctuate 1 to $2 \mathrm{ft}$ annually, as shown in the hydrograph of well Be-377 (fig. 4), located in northwestern Beauregard Parish near the town of Merryville (fig. 1). 


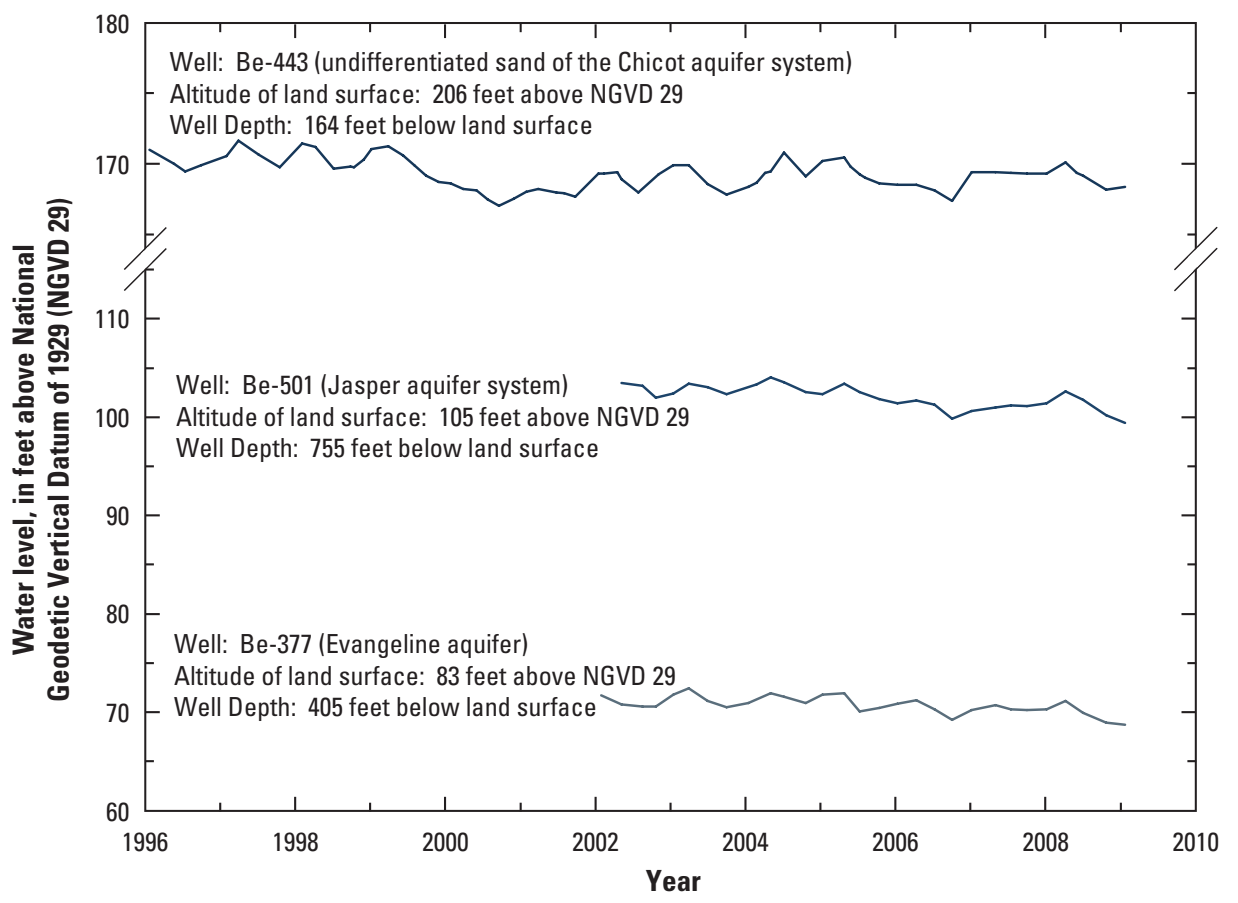

Figure 4. Water levels in well Be-443 screened in the Chicot aquifer system, in well Be-377 screened in the Evangeline aquifer, and in well Be-501 screened in the Jasper aquifer system in Beauregard Parish, Louisiana (see fig. 1 for well locations; U.S. Geological Survey, 2012c). Land surface is measured in feet above the National Geodetic Vertical Datum of 1929 (NGVD 29).

Table 3. Summary of selected water-quality characteristics for freshwater in the Chicot aquifer system (undifferentiated sand), Evangeline aquifer, and Jasper aquifer system in Beauregard Parish, Louisiana (U.S. Geological Survey, 2012e).

[Values are in milligrams per liter, except as noted. ${ }^{\circ} \mathrm{C}$, degrees Celsius; PCU, platinum cobalt units; $\mu \mathrm{S} / \mathrm{cm}$, microsiemens per centimeter; SU, standard units; $\mathrm{CaCO}_{3}$, calcium carbonate; $\mu \mathrm{g} / \mathrm{L}$, micrograms per liter; $<$, less than; NA, not applicable; SMCL, Secondary Maximum Contaminant Level established by the U.S. Environmental Protection Agency (2011)]

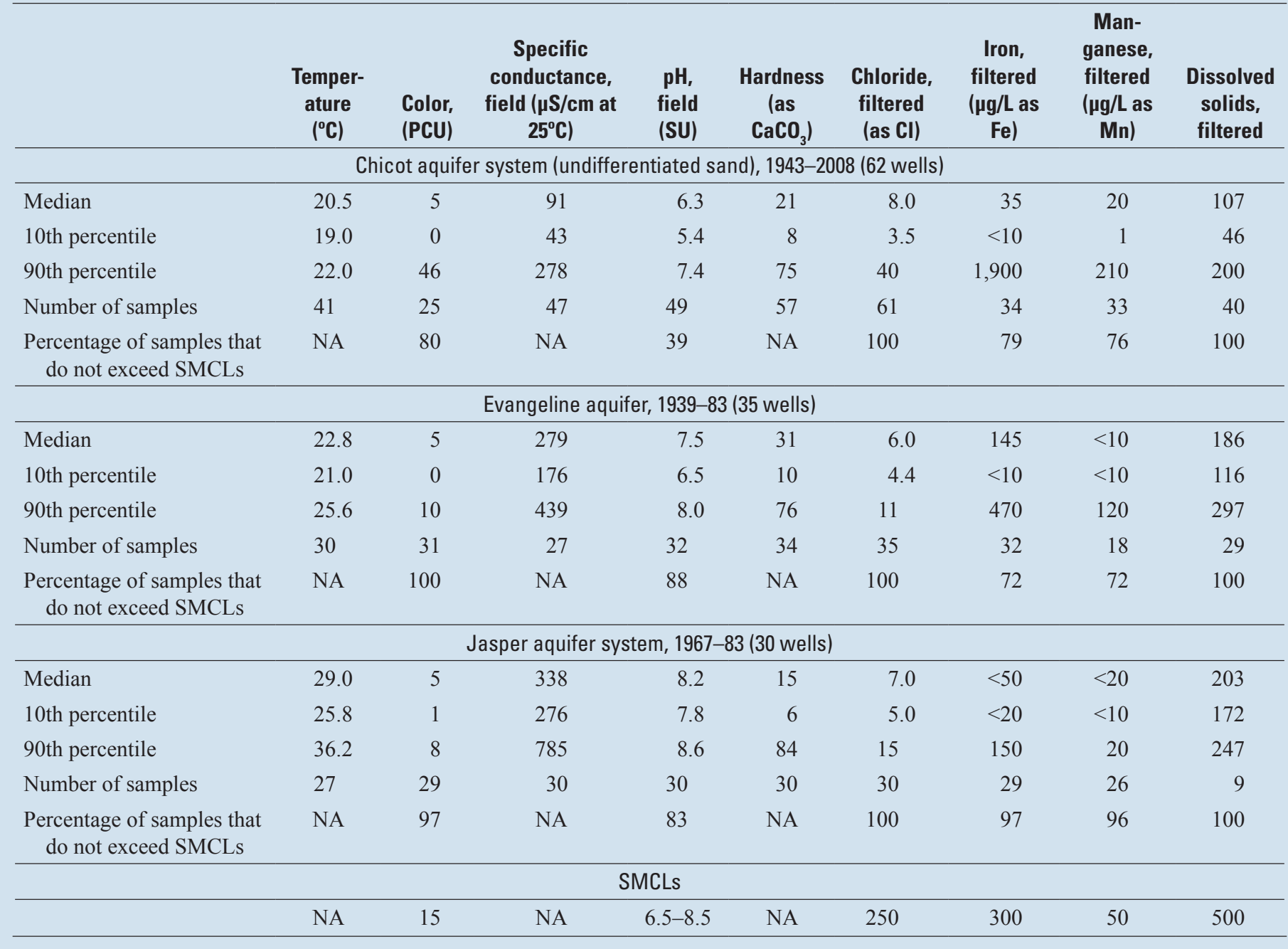


State well-registration records listed 39 active wells screened in the Evangeline aquifer in Beauregard Parish in 2009, including 24 domestic, 10 public supply, 4 irrigation wells, and 1 industrial well. Depths of these wells ranged from 155 to $1,696 \mathrm{ft}$ below land surface, with a median depth of $394 \mathrm{ft}$. Reported yields from wells screened in the Evangeline aquifer in Beauregard Parish range from about 1 to $950 \mathrm{gal} / \mathrm{min}$. In 2005, withdrawals from the Evangeline aquifer in Beauregard Parish were about 3.19 Mgal/d (table 1) and included about $1.13 \mathrm{Mgal} / \mathrm{d}$ for public supply, $1.72 \mathrm{Mgal} / \mathrm{d}$ for industrial use, $0.03 \mathrm{Mgal} / \mathrm{d}$ for rural domestic use, $0.27 \mathrm{Mgal} / \mathrm{d}$ for rice irrigation, and $0.03 \mathrm{Mgal} / \mathrm{d}$ for general irrigation.

A statistical summary of selected water-quality characteristics for 35 wells screened in freshwater areas of the Evangeline aquifer in Beauregard Parish is listed in table 3. Generally, water from the Evangeline aquifer is soft $(60 \mathrm{mg} / \mathrm{L}$ or less as calcium carbonate) and does not exceed SMCLs for drinking water for color, $\mathrm{pH}$, and chloride, iron, manganese, and dissolved solids concentrations. Locally, iron and manganese concentrations may exceed the SMCLs of 300 and $50 \mu \mathrm{g} / \mathrm{L}$, respectively.

\section{The Jasper Aquifer System}

The Jasper aquifer system, continuous throughout Beauregard Parish, underlies the Castor Creek confining unit and overlies the clayey Lena confining unit. The system consists of, from shallowest to deepest, the Williamson Creek aquifer, Dough Hills confining unit, and Carnahan Bayou aquifer (fig. 3). Light-gray sands with occasional traces of granulesize gravel make up approximately 50 percent of the aquifers within the system. The predominantly sandy Williamson Creek and Carnahan Bayou aquifers are composed of generally well sorted, very fine to medium sands interbedded with greenishgray clays. Beds of lignite (a low ranking form of coal) are commonly interbedded with sand and clay in the upper part of the Jasper aquifer system. The altitude of the top of the aquifer system is about 1,000 ft below NGVD 29 near the town of DeRidder and about 3,000 ft below NGVD 29 near the southeast corner of the parish. The regional dip of the Jasper aquifer system is to the south and southeast. Thickness of the Jasper aquifer system in Beauregard Parish generally ranges from about 2,400 ft in northern Beauregard Parish to about $3,000 \mathrm{ft}$ in the southeastern corner of the parish.

The Jasper aquifer system generally contains freshwater throughout its vertical extent only along the northern parish line and contains only saltwater in the southeastern part of the parish. The saltwater extends northward in the aquifer system as a thinning wedge and is present in the Carnahan Bayou aquifer throughout much of Beauregard Parish (fig. 3). The base of freshwater is deepest (greater than 3,000 ft below NGVD 29) in the northern third of the parish where the Carnahan Bayou aquifer contains freshwater. Southward, the base of freshwater is located in the Williamson Creek aquifer at depths greater than 2,500 ft below NGVD 29 near the towns of Oretta, Gordon, and Ragley (fig. 1).

Few water-level data for the Carnahan Bayou aquifer are available for Beauregard Parish; however, in 2003 water levels in the Williamson Creek aquifer in northern Beauregard
Parish ranged from about $100 \mathrm{ft}$ above NGVD 29 near the northwestern corner of the parish to about $60 \mathrm{ft}$ above NGVD 29 near the northeastern corner of the parish. In 2003, water levels were about $51 \mathrm{ft}$ above NGVD 29 at a small cone of depression in the water-level surface west of DeRidder, caused by industrial withdrawals in that area. Water levels in the Jasper aquifer system generally fluctuate $1-3 \mathrm{ft}$ annually, as shown in the hydrograph of well Be-501 (fig. 4), located in northwestern Beauregard Parish (fig. 1).

State well-registration records listed 19 active water wells screened in the Jasper aquifer system in Beauregard Parish in 2009, including 11 industrial, 7 public supply, and 1 irrigation well. Depths of these wells ranged from 755 to $3,736 \mathrm{ft}$ below land surface with a median depth of 1,280 ft. Reported yields from wells screened in the Jasper aquifer system in Beauregard Parish range from about 10 to 3,540 gal $/ \mathrm{min}$. In 2005, withdrawals from the Jasper aquifer system in Beauregard Parish were about 14.9 Mgal/d (table 1) and included about $0.16 \mathrm{Mgal} / \mathrm{d}$ for public supply, $14.7 \mathrm{Mgal} / \mathrm{d}$ for industrial use, and $0.01 \mathrm{Mgal} / \mathrm{d}$ for livestock.

A statistical summary of selected water-quality characteristics for 30 wells screened in freshwater areas of the Jasper aquifer system in Beauregard Parish is listed in table 3. Generally, freshwater in the aquifer system is soft and does not exceed SMCLs for drinking water for color, $\mathrm{pH}$, and chloride, iron, manganese, and dissolved solids concentrations. Locally, $\mathrm{pH}$ may exceed the SMCL of 8.5.

\section{Surface-Water Resources}

In 2005, an estimated $0.10 \mathrm{Mgal} / \mathrm{d}$ of surface water was withdrawn from miscellaneous streams in Beauregard Parish for general irrigation and livestock use. Major streams in the parish include the Sabine River, Bayou Anacoco, Barnes Creek, Bear Head Creek, Beckwith Creek, Bundick Creek, Hickory Branch, and Whisky Chitto Creek (fig. 1). Bundick Lake is a reservoir formed by an earthfill dam with a concrete spillway. Reservoir capacity at the spillway crest is 57,500 acre-feet, and the normal storage volume is 9,200 acre-feet. The surface area of the reservoir is 1,750 acres. The reservoir is used for flood control and conservation (U.S. Geological Survey, 2012a).

The mean discharge for the Sabine River near Bon Wier, Texas (station number 08028500; fig. 1) from 1961 to 2009 was 6,680 cubic feet per second (U.S. Geological Survey, 2012b). The drainage area of the Sabine River at this site, located on U.S. Highway 190 west of Merryville, is about 8,230 square miles. Water samples analyzed during the period 1969-2009 (table 4) indicate water in the Sabine River is soft and generally does not exceed the SMCLs for drinking water for $\mathrm{pH}$ and for chloride, sulfate, and iron concentrations. Dissolved oxygen is generally greater than $5 \mathrm{mg} / \mathrm{L}$, which is considered the minimum value for a diversified population of fresh, warm-water biota, including sport fish (Louisiana Department of Environmental Quality, 2008). 
Table 4. Summary of selected water-quality characteristics for the Sabine River near Bon Wier, Texas, 1969-20091.

[Values are in milligrams per liter, except as noted. ${ }^{\circ} \mathrm{C}$, degrees Celsius; $\mu \mathrm{S} / \mathrm{cm}$, microsiemens per centimeter; $\mathrm{SU}$, standard units; $\mu \mathrm{g} / \mathrm{L}$, micrograms per liter; $\mathrm{CaCO}_{3}$, calcium carbonate; NA, not applicable; SMCL, Secondary Maximum Contaminant Level established by the U.S. Environmental Protection Agency (2011)]

\begin{tabular}{|c|c|c|c|c|c|c|c|c|c|c|}
\hline & $\begin{array}{c}\text { Specific } \\
\text { conductance, } \\
\text { field }(\mu \mathrm{S} / \mathrm{cm} \\
\left.\text { at } 25^{\circ} \mathrm{C}\right)\end{array}$ & $\begin{array}{l}\text { Oxygen, } \\
\text { dis- } \\
\text { solved }\end{array}$ & $\begin{array}{l}\text { pH, } \\
\text { field } \\
\text { (SU) }\end{array}$ & $\begin{array}{l}\text { Hard- } \\
\text { ness (as } \\
\mathrm{CaCO}_{3} \text { ) }\end{array}$ & $\begin{array}{c}\text { Calcium, } \\
\text { filtered } \\
\text { (as Ca) }\end{array}$ & $\begin{array}{c}\text { Mag- } \\
\text { nesium, } \\
\text { filtered(as } \\
\mathrm{Mg} \text { ) }\end{array}$ & $\begin{array}{l}\text { Sodium, } \\
\text { filtered } \\
\text { (as Na) }\end{array}$ & $\begin{array}{l}\text { Chlo- } \\
\text { ride, } \\
\text { filtered } \\
\text { (as CI) }\end{array}$ & $\begin{array}{l}\text { Sulfate, } \\
\text { filtered } \\
\left(\text { as } \mathrm{SO}_{4} \text { ) }\right.\end{array}$ & $\begin{array}{l}\text { Iron, un- } \\
\text { filtered, } \\
\text { ( } \mu \text { g/Las } \\
\text { Fe) }\end{array}$ \\
\hline Median & 153 & 8.4 & 7.2 & 38 & 9.7 & 2.7 & 22 & 17 & 18 & 50 \\
\hline 10 th percentile & 112 & 6.7 & 6.6 & 26 & 7.4 & 1.6 & 12 & 12 & 11 & 20 \\
\hline 90th percentile & 213 & 9.9 & 7.5 & 46 & 13 & 3.9 & 30 & 27 & 28 & 160 \\
\hline $\begin{array}{l}\text { Percentage of sam- } \\
\text { ples that do not } \\
\text { exceed SMCLs }\end{array}$ & NA & NA & 96 & NA & NA & NA & NA & 100 & 100 & 93 \\
\hline \multicolumn{11}{|c|}{ SMCLs } \\
\hline & NA & NA & $6.5-8.5$ & NA & NA & NA & NA & 250 & 250 & 300 \\
\hline
\end{tabular}

${ }^{1}$ Station number 08028500 (U.S. Geological Survey, 2012d).

\section{Selected References}

Brantly, J.A., and Seanor, R.C., 2005, Louisiana ground-water map no. 18: Potentiometric Surface, 2003, Jasper aquifer system in west-central Louisiana: U.S. Geological Survey Scientific Investigations Map 2861, 2 sheets.

Fendick, R.B., Jr., 2005, Louisiana ground-water map no. 21: Generalized potentiometric surface of the Evangeline aquifer in south-central Louisiana, January-March 2004: U.S. Geological Survey Scientific Investigations Map 2880, 1 sheet, accessed January 24, 2012 at http://pubs.usgs.gov/sim/2880/plate-1.pdf.

Louisiana Department of Environmental Quality, 2008, Environmental Regulatory Code, Title 33, Part IX, Subpart 1, accessed June 9, 2009, at http:www.deq.louisiana.gov/portal/tabid/1674/Default.aspx.

Louisiana Department of Transportation and Development, 1986, Official map of Louisiana - 1986 edition: Baton Rouge, Louisiana, Louisiana Department of Transportation and Development, 1 sheet.

Lovelace, J.K., Fontenot, J.W., and Frederick, C.P., 2004, Withdrawals, water levels, and specific conductance in the Chicot aquifer system in southwestern Louisiana, 2000-03: U.S. Geological Survey Scientific Investigations Report 2004-5212, 56 p, accessed July 25, 2012, at http://la.water.usgs.gov/publications/pdfs/SIR_2004-5212.pdf.

Sargent, B.P., 2007, Water use in Louisiana, 2005: Louisiana Department of Transportation and Development Water Resources Special Report no. $16,133 \mathrm{p}$.

Smoot, C.W., 1988, Louisiana hydrologic atlas map no. 3: Altitude of the base of freshwater in Louisiana: U.S. Geological Survey WaterResources Investigations Report 86-4314, 1 sheet, accessed November 2, 2011, at http://pubs.usgs.gov/wri/1986/4314/plate-1.pdf.

U.S. Environmental Protection Agency, 1992, Secondary Drinking Water Regulations - guidance for nuisance chemicals: U.S. Environmental Protection Agency publication EPA 810/K-92-001, 4 p., accessed September 28, 2011, at http://water.epa.gov/drink/contaminants/ secondarystandards.cfm.

U.S. Environmental Protection Agency, 2011, 2011 Edition of the drinking water standards and health advisories: U.S. Environmental Protection Agency publication EPA 820-R-11-002, Office of Water, 12 p., accessed September 2, 2011 at http://water.epa.gov/action/advisories/drinking/ upload/dwstandards2011.pdf.

U.S. Geological Survey, 2012a, Annual water-data report 2008 [for gage 08014881 Bundick Lake at Spillway near DeRidder, LA]: U.S.Geological Survey Water Resources of the United States, Publications-Annual Water Data Reports, accessed January 7, 2010, at http://wdr.water.usgs.gov/wy2008/pdfs/08014881.2008.pdf.
U.S. Geological Survey, 2012b, Annual water-data report 2009 [for gage 08028500 Sabine River near Bon Wier, TX]: U.S.Geological Survey Water Resources of the United States, Publications-Annual Water Data Reports, accessed January 7, 2011, at http://wdr.water.usgs.gov/wy2009/ pdfs/08028500.2009.pdf.

U.S. Geological Survey, 2012c, Ground-water levels for Louisiana: National Water Information System Web Interface, accessed January 7, 2010, at http://nwis.waterdata.usgs.gov/la/nwis/gwlevels.

U.S. Geological Survey, 2012d, Water Quality Samples for Texas [data for USGS 08028500 Sabine Rv nr Bon Wier, TX.]: National Water Information System Web Interface, accessed January 7, 2010, at http:// nwis.waterdata.usgs.gov/tx/nwis/qwdata/?site_no $=08028500$.

U.S. Geological Survey, 2012e, Water quality samples for Louisiana: National Water Information System Web Interface, accessed February 3, 2010, at http://nwis.waterdata.usgs.gov/la/nwis/qwdata/.

Whitfield, M.S., Jr., 1975, Geohydrology of the Evangeline and Jasper aquifers of southwestern Louisiana: Department of Conservation, Louisiana Geological Survey, and Louisiana Department of Public Works Water Resources Bulletin no. 20, 72 p.

\section{By Lawrence B. Prakken , Jason M. Griffith, and Robert B. Fendick, Jr.}

\section{For additional information, contact:}

Director, USGS Louisiana Water Science Center 3535 S. Sherwood Forest Blvd., Suite 120

Baton Rouge, LA 70816

E-mail: dc_la@usgs.gov

Fax: (225) 298-5490

Telephone: (225) 298-5481

Home Page: http://la.water.usgs.gov

This fact sheet was published by the U.S. Geological Survey, in cooperation with the Louisiana Department of Transportation and Development (DOTD). Thanks are given to Zahir "Bo" Bolourchi, Director, Water Resources Programs, Louisiana Department of Transportation and Development, who contributed to the content and design of the fact sheet. 